\title{
Revitalisasi Pemasaran Produk bagi Rumah Tangga Pengolah Gula Kelapa di Ujung Genteng, Kabupaten Sukabumi
}

\author{
Gidion Putra Adirinekso ${ }^{1}$, Adrie Frans Assa ${ }^{2}$ \\ ${ }^{1,2}$ Jurusan Manajemen, Fakultas Ekonomi dan Bisnis, Universitas Kristen Krida Wacana \\ Jl. Tanjung Duren Raya No. 4. Jakarta Barat. \\ ${ }^{1}$ gidion.adirinekso@ukrida.ac.id \\ 2 adrie.assa@ukrida.ac.id
}

\begin{abstract}
Abstrak-Masyarakat di Ujung Genteng, Ciracap, Kabupaten Sukabumi sebagian penduduknya berprofesi sebagai pengolah gula kelapa dikarenakan sudah sejak jaman penjajahan Belanda perkebunan kelapa dikembangkan sehingga secara turun temurun pemanfaatan Nira menjadi gula kelapa menjadi mata pencaharian penduduk. Sudah sejak lama profesi ini muncul dan berkembang menjadi salah satu aktivitas penyokong ekonomi masyarakat. Dinamika usaha / industri olahan ini dipengaruhi oleh banyak faktor, seperti proses produksi, keuangan dan permodalan, maupun distribusi produk dan pemasaran. Tujuan pengabdian masayarakat bagi Pengolah gula kelapa di Ujung Genteng, adalah mencari solusi bersama atas masalah pemasaran dan perluasannya. Melalui diskusi yang inten dengan berbagai rumah tangga usaha, pengolah gula kelapa, disepakati membuat program pemasaran untuk meningkatkan kelangsungan usaha tersebut. Bentuk detil programnya adalah berupa pelatihan dan pendampingan kepada pengolah gula kelapa yang dirumuskan bersama-sama. Pengabdian masyarakat yang sedang berlangsung ini telah menghasilkan beberapa dampak. Pertama, muncul keinginan memperluas pasar bagi sebagian besar rumah tangga pengolah gula kelapa; Kedua, dilakukan uji coba atau try out bagi beberapa rumah tangga pengolah gula kelapa untuk memperluas pasar dengan membuat jejaring dengan sistem gethok tular menggunakan
\end{abstract}

teknologi komunikasi yang ada; Ketiga, Beberapa rumah tangga usaha pengolah gula kelapa telah merasakan manfaat dari segi peningkatan pendapatan; Keempat, timbulnya kesadaran dan keinginan sebagian besar rumah tangga untuk mendifferensiasi produknya berdasarkan informasi dari jejaring yang mereka bentuk sebelumnya. Hal keempat ini sedang dalam proses untuk ditindaklanjuti serius dengan memperhitungkan manfaat dan risiko yang akan diterima.

Kata kunci-rumah tangga Pengolah gula kelapa, revitalisasi, perluasan pasar.

\begin{abstract}
Some of the population work as coconut sugar processors in Ujung Genteng, Ciracap, Sukabumi Regency. Since the Dutch colonial era, coconut plantations have been developed so that from generation to generation, the use of Nira into coconut sugar has become the livelihood of the residents. It has been a long time since this profession emerged and developed into one that supports the community's economy. The dynamics of this processed business/industry are influenced by many factors, such as the production process, finance and capital, and product distribution and marketing. The purpose of community service for coconut sugar processors in Ujung Genteng is to find joint solutions to marketing problems and their expansion. Through intense discussions with various business households, coconut sugar processors, it was agreed to create a marketing program to improve the continuity of the business. The detailed form of the program is in the form of training and mentoring for coconut sugar processors, which are formulated together. This ongoing community service has had several impacts. First, there is a desire to expand the market for the majority of coconut sugar processing households; Second, a trial was conducted for several coconut sugar processing households to expand the market by establishing a network with a "gethok tular" system using existing communication technology; Third, some coconut business households have benefited from an increase in income; Fourth, the emergence of awareness and desire of most households to differentiate their products based on information from the networks they previously formed. This fourth thing is in the process of being followed up seriously by taking into account the benefits and risks that will be received
\end{abstract}

Keywords: coconut sugar craftsman households, revitalization, market expansion

\section{PENDAHULUAN}

UjungGenteng,sebuah desa di Kecamatan Ciracap, Kab upaten Sukabumi Jawa Barat merupakan hasil pemekaran Desa Gunung batu sesuai dengan Peraturan Daerah Kabupaten Sukabumi Nomor 10 Tahun 2008. Letak 
Ujung Genteng $\pm 23 \mathrm{~km}$ dari ibukota Kecamatan Ciracap, $170 \mathrm{~km}$ dari Ibukota Kabupaten (Sukabumi) dan $270 \mathrm{~km}$ dari ibukota Provinsi Jawa Barat [1]. Terkait akses ke desa, desa ini cukup mudah dijangkau karena desa ini dilintasi jalan provinsi. Oleh karenanya dari Ciracap ke Ujung Genteng hanya perlu waktu sekitar 23 menit, dari Sukabumi 3,5 jam, dan dari Bandung 8 jam. Secara administratif, Desa Ujung Genteng berbatasan dengan Desa Gunung Batu, Desa Pangumbahan, Kecamatan Ciracap di Barat, Desa Cikangkung, Kecamatan Surade di Timur, Kecamatan Waluran di Sebelah Utara, dan Samudara Hindia di Selatan,

Kawasan Ujung Genteng memiliki potensi sumber daya alam yang kaya berupa beberapa tempat wisata yang gemar dikunjungi oleh wisatawan asing dan juga beberapa industri kreatif. Desa Ujung Genteng memiliki luas 1.870 ha. Sebagian besar lahan dari Desa Ujung Genteng adalah lahan pekarangan $(37,42 \%)$. Meskipun demikian, terdapat pula lahan pemukiman, persawahan, perkebunan, dan hutan. Untuk wilayah perkebunannya, Desa Ujung Genteng didominasi oleh perkebunan kelapa yaitu sekitar 200 ha $(57,14 \%)$ dari total 350 ha lahan perkebunan. Luasnya lahan perkebunan kelapa ini masuk akal karena desa ini merupakan wilayah eks PTPN Cigebang [1].

Keberadaan perkebunan kelapa yang cukup luas inilah yang kemudian menjadikan sebagian masyarakat di Ujung Genteng berprofesi sebagai pengrajin gula kelapa. Sudah sejak lama profesi ini muncul dan berkembang menjadi salah satu aktivitas penyokong ekonomi masyarakat. Bahkan, tidak sedikit pengrajin gula kelapa ini dijadikan sebagai pekerjaan utama penduduk setempat. Mereka memilih pekerjaan ini sebagai pekerjaan utama karena minimnya penghasilan jika mereka tetap pada pekerjaan sebelumnya yaitu sebagai nelayan dan petani. Selain itu, faktor sulitnya akses terhadap lapangan pekerjaan karena minimnya pendidikan yang dimiliki serta kurangnya peran serta pemerintah membuat penduduk setempat tidak memiliki pilihan lain.

Pengembangan industri rumah tangga gula kelapa di Desa Ujung Genteng, menunjukkan bahwa pengrajin melakukan kegiatan usahanya dengan skala rumah tangga. Namun, meskipun dilakukan dengan skala rumah tangga dan masih bersifat tradisional, kegiatan pengolahan gula kelapa di Ujung Genteng masih dapat bertahan hingga saat ini ditengah persaingan dengan industri sejenis dari daerah lain [2].

Dinamika usaha / industri olahan semacam ini dipengaruhi oleh banyak faktor, seperti proses produksi, keuangan dan permodalan, maupun distribusi produk dan pemasaran [3]. Dari berbagai faktor yang mempengaruhi dinamika industri tersebut, dilihat dari kepentingan rumah tangga usaha maka masalah perluasan pasar menjadi salah satu faktor penting yang menjadi prioritas untuk diupayakan pencapaiannya. Hal tersebut berimplikasi pada peningkatan dan keberlangsungan pendapatan rumah tangga usaha pada indutri tersebut. Namun, selain pengerjaannya yang dilakukan secara tradisional, pemasarannya pun masih dilakukan secara tradisional. Hal ini sangat berpengaruh terhadap besaran penghasilan para pengrajin gula kelapa ini. Oleh karena itu, tim pengabdian masyarakat Ukrida melakukan pengabdian masyarakat bagi pengrajin gula klapa di Desa Ujung Genteng.

Tujuan pengabdian masayarakat bagi pengrajin gula kelapa di Ujung Genteng adalah mencari solusi bersama atas masalah pemasaran dan perluasannya. Melalui diskusi yang intens dengan berbagai rumah tangga usaha pengrajin gula kelapa, disepakati membuat program pemasaran daring untuk meningkatkan kelangsungan usaha tersebut. Bentuk detil programnya adalah berupa pelatihan dan pendampingan kepada pengrajin yang dirumuskan secara bersama-sama. Diharapkan dengan adanya pelatihan dan pendampingan kepada pengrajin gula kelapa di Desa Ujung Genteng ini, pengrajin dapat memperluas pemasaran gula kelapa. Cara termudah yang dilakukan adalah memanfaatkan komunikasi Whatsapp Group, dan menjajagi pemanfaatan platform online seperti e-commerce yang dapat dilakukan secara mudah lewat telepon pintar yang dimiliki pengrajin. Perluasan pemasaran ini diharapkan akan berdampak langsung pada peningkatan penghasilan para pengrajin gula kepala ini.

\section{METODE}

Pengabdian kepada masyarakat ini dilakukan pada Desa Ujung Genteng, Sukabumi, Jawa Barat. Pelaksanaan kegiatan PKM ini dilakukan sejak awal Mei 2021 hingga sekarang. Dimulai dengan tahap preliminary study dengan observasi dan kunjungan langsung ke Desa Ujung Genteng. Dilanjutkan dengan diskusi intens untuk menemukan permasalahan dalam bentuk Focus Group Disscussion, hingga disepakati penyusunan program abmas. Untuk merealisasikan program abmas, dilakukan persiapan pelatihan dan pendampingan, dengan menyiapkan modul pelatihan. Kegiatan pelatihan dan pendampingan pada rumah tangga pengrajin gula kelapa dilakukan di lokasi, kemudian diikuti evaluasi dan pelaporan kegiatan.

Persiapan kegiatan pengabdian diawali dengan melakukan pengurusan perijinan kepada Kepala Desa Ujung Genteng dan koordinasi dengan pengrajin setempat untuk melakukan diskusi serta pelatihan dan pendampingan terkait dengan perluasan pemasaran gula kelapa oleh pengrajin di Desa Ujung Genteng. Hal ini terlebih dahulu dilakukan agar pelaksanaan kegiatan dapat memecahkan permasalahan yang dihadapi dan dapat mencapai tujuan bersama untuk meningkatkan penghasilan pengrajin gula kelapa yaitu dengan adanya pelatihan dan pendampingan dalam rangka perluasan pemasaran Gula Kelapa di Ujung Genteng. 
Luas wilayah desa Ujung Genteng ialah 1.870 ha. Pemanfaatan lahan sebagian besar terbagi atas lahan pekarangan $(37,42 \%)$, lahan perkebunan didominasi oleh perkebunan kelapa yaitu sekitar 200 ha $(57,14 \%)$ dari total 350 ha lahan perkebunan. Luasnya lahan perkebunan kelapa tidaklah mengherankan karena daerah ini merupakan wilayah eks PTPN Cigebang.

Sektor perkebunan negara telah menarik para pengusaha yang melihat peluang usaha yang tersisa dari sektor perkebunan. Usaha perkebunan tersebut diambil alih dengan sistem Hak Guna Usaha (dalam masa 30-35 tahun). Sejak 1985 sampai dengan saat ini telah terjadi dua kali pengalihan HGU di lahan eks-PTPN, yaitu PT. Brajatama dan yang terakhir PT. Bumi Lestari Abadi (BLA).

Sistem kerjasama antara PT. BLA (pemegang HGU saat ini) dengan masyarakat (pengolah gula kelapa) di Desa Ujung Genteng dilakukan untuk mengoptimalkan potensi perkebunan kelapa seluas 200 ha dengan memproduksi gula kelapa. Penduduk mulai membuat gula kelapa pada tahun 90 an.

Pengolah gula kelapa umumnya selalu tergantung dengan para pengepul dalam penyediaan modal produksi yang dengan terpaksa menyerahkan hasil produksi gula kelapa dalam sistem bagi hasil maupun penjualan dengan harga yang lebih murah dari harga pasar dalam volume yang tetap kepada pihak pengepul. Pemberian modal kepada pengolah merupakan strategi pengepul melakukan kerja sama dengan memanfaatkan kebutuhan pengarajin gula kelapa, untuk membeli gula kelapa dengan harga yang lebih murah dibandingkan harga pasar namun sedikit lebih tinggi dari harga gula yang dijual Pengolah ke PT. BLA. Pembayaran utang Pengolah hanya dihitung utang pokoknya saja, tanpa bunga.

Usaha pembuatan gula kelapa dilakukan secara tradisional dengan teknologi yang masih sederhana[4] . Nira sebagai sumber bahan baku gula kelapa diperoleh dengan menyadap yang dimulai dengan cara mengikat bunga kelapa (manggar), lalu memotong manggar untuk diambil niranya. Semula nira ditampung menggunakan bambu, namun saat ini digantikan dengan jaligen karena sifat bambu yang dinilai kurang efektif, mudah jatuh dari pohon dan pecah. Nira hasil sadapan langsung diolah di atas tungku dengan waktu antara 4-5 jam, bahkan di musim penghujan proses pemasakan memerlukan tambahan waktu 1 sampai 2 jam. Setelah nira di atas tungku mengental, barulah kuali diangkat, kemudian dilanjutkan pengadukan yang dilanjutkan dengan pencetakan, pengemasan lalu penjualan. Proses pencetakan dilakukan dengan alat cetak yang terbuat dari plastik. Proses pengemasan di plastik berisi 10 buah kelapa, dengan berat rata-rata $1 \mathrm{~kg}$ per unit. Bahan bakar untuk membuat gula kepala adalah berbagai jensi kayu. Dari gambaran produksi ini, persoalan efisiensi produksi [5] perlu diperhatikan. Proses pembuatan gula kelapa secara tradisional terlihat pada gambar 1

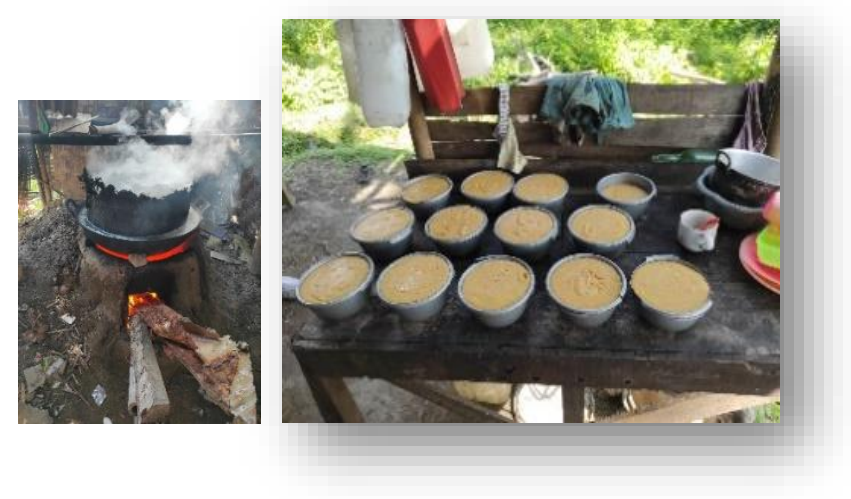

Gambar 1. Proses pengolahan gula kelapa

Pengolah gula kelapa termasuk ke dalam industri rumah tangga. Pengolahan gula kelapa dilakukan secara berkelompok terdiri dari 10 sampai 15 orang. Per orang mempunyai tugas untuk menyadap nira dan mengambil hasil sadapannya. Pengolahan air Nira menjadi gula kelapa dilakukan secara bersama-sama. 1 orang memanjat 50 pohon per hari naik dan turun untuk mengambil hasil sadapan Nira. Pohon kelapa yang disadap adalah kelapa hibrida (varietas Kina) yang ditanam tahun 1986 sekarang berumur sekitar 35 tahun. Dalam seminggu, 70 pohon kelapa mampu menghasilkan 1,5 kwintal gula kelapa.

Sudah sejak lama profesi ini muncul dan berkembang menjadi salah satu aktivitas penyokong ekonomi masyarakat. Dinamika usaha / industri olahan ini dipengaruhi oleh banyak faktor, seperti proses produksi, keuangan dan permodalan, maupun distribusi produk dan pemasaran. Dari berbagai faktor yang mempengaruhi dinamika industri tersebut, dilihat dari kepentingan rumah tangga usaha maka masalah perluasan pasar menjadi salah satu faktor penting yang menjadi prioritas untuk diupayakan pencapaiannya. Hal tersebut berimplikasi pada peningkatan dan keberlangsungan pendapatan rumah tangga usaha pada indutri tersebut, seperti halnya terjadi di Desa Gondang Manis, Kecamatan Bae, Kabupaten Kudus[6].

Penghasilan dari membuat gula kelapa dirasakan pengolah relatif cukup untuk memenuhi kebutuhan rumah tangga. Hal tersebut mengkonfirmasi analisis pendapatan gula merah di Dea Lembang Lohe, Kecamatan Kajang, Kabupaten Bulukumba [7] Untuk menambah penghasilannya banyak pengolah melakukan pekerjaan lain seperti nelayan atau ojek. Para pengolah memiliki rumah jauh dari lokasi perkebunan sehingga harus menyewa rumah untuk mengolah nira

Melalui diskusi yang inten dengan berbagai rumah tangga usaha Pengolah gula kelapa, disepakati membuat program pemasaran untuk meningkatkan kelangsungan usaha tersebut. Bentuk detil programnya adalah berupa pelatihan dan pendampingan kepada Pengolah yang dirumuskan bersama-sama. 
Pengabdian masyarakat yang sedang berlangsung ini telah menghasilkan beberapa dampak. Muncul keinginan memperluas pasar bagi sebagian besar rumah tangga Pengolah gula kelapa dengan menjual bukan hanya kepada pengepul atau tengkulak tetapi membuka jejaring dengan pasar tradisional dan digital marketing. Para pengolah gula kelapa telah diberikan pelatihan menggunakan media sosial dan e-commerce untuk memperluas penjualan.

Dilakukan uji coba atau try out bagi beberapa rumah tangga Pengolah gula kelapa untuk memperluas pasar dengan membuat jejaring melalui sistem gethok tular menggunakan teknologi komunikasi yang ada. Membuka mata dan telinga dengan lebih luas membuka jaringan usaha. Gethok tular merupakan pemasaran dari mulut ke mulut. Penggunaan strategi ini mengedepankan kualitas produk sehingga pengguna produk ini ketika merasakan baiknya produk yang dihasilakn akan menyampaikan kepada orang lain dan berharap orang tersebut akan menggunakan produk yang sama dan terus berlanjut.

Para rumah tangga pengolah gula juga secara intens menggunakan jejaring yang dimiliki untuk memperluas pasar dan mengurangi ketergantungan kepada para tengkulak atau pengepul dengan cara "gethok tular" tersebut.

Hasil perluasan pasar yang dilakukan disertai pendampingan dari tim abmas telah berdampak kepada pasar yang semakin luas dan beberapa rumah tangga usaha Pengolah gula kelapa telah merasakan manfaat dari segi peningkatan pendapatannya. Tren peningkatan pendapatan sejak diterapkannya pelatihan yang dilakukan, secara perlahan tapi pasti semakin memperkokoh posisi tawar Pengolah gula kelapa terhadap para Pengepul, khususnya dalam penentuan harga jual, dan keberlangsungan usaha mereka.

Tantangan yang dihadapi para Pengolah gula kelapa tidak mudah. Keraguan akan kepastian bahwa upaya ini bisa berlangsung terus masih melingkupi. Karakteristik ini juga terjadi di wilayah Kebumen, Medan, Kabupaten Semarang, Bulukumba dan lainnya[7] [8][9][10] Hal kedua adalah upaya untuk mengajak rumah tangga usaha pengolah gula kelapa lain yang belum bergabung. Dan ketiga, kesulitan likuiditas keuangan dan kemudahan menjual, seringkali memperlemah usaha mereka untuk memperluas pasar sehingga sebagian kembali ke pengepul. Hal ini bersesuaian dengan hasil penelitian dari Muhsoni, Karyadi dan Hasrati[8].

Di sisi lain, dampak dari upaya perluasan pasar ini telah menimbulnya kesadaran dan keinginan sebagian besar rumah tangga untuk mendifferensiasi produknya. Informasi dari jejaring yang mereka bentuk untuk perluasan pasar. Hal keempat ini sedang dalam proses untuk ditindaklanjuti serius dengan memperhitungkan manfaat dan risiko yang akan diterima. Upaya differensiasi produk akan diawali dengan pembuatan bentuk potongan gula kelapa (Marsigit, 2016) yang lazim dibuat untuk dijual di pasar tradisional yaitu bulat, gepeng dan kecil. Hal ini tidak seperti yang selama ini dijual ke pengepul bulat dan besar seperti mangkok. Differensiasi produk ini diharapkan juga menjadi salah satu upaya untuk memecah ketergantungan ke Pengepul, dan memperluas pasar. Untuk itu tim abmas akan mendampingi proses menemukan differensisi produk yang tepat.

Dari kegiatan pengabdian kepada masyarakat yang terus berlanjut dengan berbagai persoalan yang akan ditangani dan dipergumulkan dengan masyarakt Desa Ujung Genteng, bisa ditarik beberpa hal. (1). Kegiatan abmas sesungguhnya harus mengajak masyarakat atau komunitas untuk menemukan akar masalah, menemukan solusi yang konstruktif, serta mampu melakukan evaluasi mandiri. (2). Komunitas yang sudah lama beraktivitas di suatu usaha, seringkali punya keengganan melakukan perbaikan atau bahkan inovasi yang bisa berdampak nyata bagi kehidupan usahanya, terlebih jika apa yang akan dikerjakan berisiko untuk gagal; (3) bagi Lembaga Pendidikan seperti universitas, mendapatkan banyak pelajaran berharga dari komunikasi dan interaksi yang dilakukan, sehingga bisa dipakai sebagai salah satu bahan yang memperkaya pembelajaran di dalam kelas; (4) kemampuan untuk mendekati melalui kebiasaan, cara, budaya dan Bahasa sebaiknya selalu diprioritaskan dalam proses pendekatan kepada komunitas. Komunitas yang berbeda memiliki cara pendeatan yang berbeda pula.

Langkah berikutnya yang akan dikerjakan dalam keberlangsungan program pengabdian kepada masyarakat di Desa Ujung Genteng adalah: (1). Memonitor dan mendukung serta mengarahkan kepada proses yang benar dalam melakukan program perluasan pasar; (2). Menyeiapkan program abmas berikutnya terkait proses produksi, dan kaitannya dengan Kesehatan, dan keselamatan kerja mulai dari penuairan nira, pengolahan, hingga pendistribusiannya; (3) pengembangan produk dalam berbagai bentuk produk bisa dikembangkan Bersama komunitas untuk peningkatan pendapatan mereka.

\section{KESIMPULAN}

Pengolah gula kelapa sudah melakukan pekerjaan ini selama bertahun-tahun, akibat kurangnya pengetahuan menyebabkan masyarakat hanya melakukan hal yang selama ini diketahui secara turun temurun. Diferensiasi produk atau perluasan pemasaran tanpa mengandalkan pengepul tidak terpikirkan sebelumnya. Pengolah gula kelapa terikat oleh pengepul selama puluhan tahun. Kegiatan abmas ini membuka wawasan pengolah untuk dapat mengembangkan diri untuk melakukan revitalisasi pemasaran produk gula kelapa.

\section{UCAPAN TERIMA KASIH}

Terima kasih kami sampaikan kepada Universitas Kristen Krida Wacana yang telah mendanai kegiatan pengabdian kepada masyarakat ini, sehingga peneliti dapat memberikan ilmu pengetahuan yang bermanfaat kepada masyarakat pengolah gula kelapa di Desa Ujung Genteng. 


\section{DAFTAR PUSTAKA}

[1] M. Rokhani and I. Alkhudri, "Strategi Nafkah dan Pola Pengambilan Keputusan Rumahtangga Pengrajin Gula Kelapa (Studi di Desa Ujung Genteng Kecamatan Ciracap Kabupaten Sukabumi Jawa Barat)," Sodality: Jurnal Sosiologi Pedesaan, vol. 03 , no. 3, pp. 129 - 139, 2015.

[2] F. Zuliandi, "Analisis Pengolahan Gula Kelapa Skala Rumah Tangga di Desa Ujung Genteng, Kabupaten Sukabumi, Jawa Barat. Bogor: IPB Press," Bogor University Press, Bogor, 2014.

[3] C. Machado and J. P. Davim, Theory and application of Business and Management Principles, Portugal: Springer Nature, 2016.

[4] W. Marsigit, "Perbaikan Teknologi Pengolahan, Modifikasi Bentuk dan Ukuran, Serta Pengembangan Produk Alternatif Gula Aren. Dharma Raflesia Unib, Tahun XIV, Nomor 1 Juni. Universitas Bengkulu.," Dharma Raflesia: Jurnal Ilmiah Pengembangan dan Penerapan IPTEKS, vol. Juni, no. 1, pp. 47 - 58, 2016.

[5] I. Indarwati, "Efisiensi Produksi pada Agroindustri Gula Kelapa di Kecamatan Cilongok Kabupaten Banyumas," Majalah Ilmiah Ekonomika, vol. Agustus, no. 3, pp. 128 - 137, 2009.

[6] E. C. Adriana, "Perkembangan Industri Gula Merah dan Pengaruhnya terhadap Kehidupan Sosial Ekonomi Masyarakat Desa Gondang Manis Kecamatan Bae Kabupaten Kudus Tahun 1998 - 2008," Universitas Negeri Semarang, Semarang, 2009.

[7] I. D. Tahir, "Analisis Pendapatan Pengrajin Gula Merah di Desa Lembang Lohe Kecamatan Kajang Kabupaten Bulukumba," Universitas Muhammadiyah Makassar, Makassar, 2017.

[8] Muhsoni, Karyadi and E. Hasrati, "Analisis Pemasaran Gula Kelapa Studi Kasus Di Desa Karangduren, Kecamatan Tengaran Kabupaten Semarang," Agromedia, vol. 35, no. 1, pp. 73 - 85, 2017.

[9] W. A. Malik, M. Ferichani and E. Widiyanti, "Strategi Pengembangan Usahatani Gula Kelapa di Kecamatan Puring Kabupaten Kebumen," Jurnal Sosial Ekonomi Pertanian dan Agribisnis, vol. 14, no. No. 2, pp. 105 - 113, 2018.

[10] S. H. B. Simbolon, Strategi Pemasaran Gula Merah dari Nira Kelapa Sawit di Kabupaten Serdang Bedagai, Medan: Universitas Sumatera Utara, 2020. 